\title{
Manchu Language Pedagogical Practices: The Connections Between Manuscript and Printed Books ${ }^{1}$
}

\author{
DEVIN FITZGERALD \\ UCLA Library Special Collections
}

This paper explores the history of Manchu language education during the Qing dynasty in order to reconstruct the relationships between printed pedagogical genres and their manuscript counterparts. Through a consideration of both the revolutionary nature of Manchu language pedagogy and evidence from manuscript materials in the HarvardYenching Library, it reconstructs the hypothetical progression of Manchu language students during the Qing dynasty.

\section{《論清代滿語敎學中刻本與抄本之關聯》}

\begin{abstract}
DEVIN FITZGERALD 馮坦風 加利福尼亞大學洛杉磯分校圖書館特藏部 摘要

本篇論文旨在探究大清年間滿語敎學業的發展史, 並推測出此時段滿語敎學書籍中 刻本與抄本之間的關聯。本文放慮到, 於該時段所施行的滿語教學方法, 在中國當時 的語言敎學界內是空前的。在此之上, 筆者亦在哈佛大學燕京圖書館特藏的滿文手寫 本中找到了對清朝滿語敎學業較爲直觀的記載和描述。由此, 本文得以構擬出清代人 學習滿語的經歷與體驗的逐步變化。
\end{abstract}

In the late seventeenth century, a quiet pedagogical revolution began in Qing (1636/1644-1911) China. Shen Qiliang 沈啓亮 (fl. 1645-93), a scholar interested in the Manchu language, published a book titled A Guide to Qing Writing (Qingshu zhinan 清

1. This paper is received the feedback and support of more colleagues than I can possibly enumerate. My interested in Manchu pedagogical genres was fostered by Mark Elliott in intermediate Manchu when a group of us, including Hanung Kim and He Bian, began translating Muwa gisun. The rough seminar paper that emerged was read by many, including David Porter, Eric Schluessel, and Mårten Söderblom Saarela, all of whom provided critical feedback. In addition, my 2014 panel on "Knowledge and the Manchu Book," at the AAS aired some of the early ideas to Carla Nappi, who also provided useful feedback. Several rounds of reviewers and Maura Dykstra helped to sharpen the argument. Finally, Sven Osterkamp provided encouragement and useful edits. 
書指南). To modern readers, there is little surprising about Shen's language textbook. It begins by describing the mechanics of the script, proceeds to simple phrases and model conversations, and ends in a brief chapter detailing Manchu's foreign grammar. In early modern China, however, this fusion of linguistic elements into a single pedagogically oriented text was unprecedented. ${ }^{2}$ After Shen's textbook appeared in 1682, Manchu language pedagogical genres grew in popularity. Over the course of the eighteenth century, Manchu, Mongol, and Chinese bannermen, as well as occasional Hanlin scholars, purchased such textbooks and enrolled in schools to learn Manchu. ${ }^{3}$

With the works of scholars such as Shen Qiliang in mind, this paper argues that Manchu textbooks and Manchu language pedagogical practices combined to allow for the maintenance of Manchu language proficiency until dynastic collapse in 1911. The emergence of Manchu language textbooks and associated pedagogical genres represented a major shift in Qing understandings of language and language acquisition. Without these materials, the empire would have faced even greater challenges maintaining Manchu-competent translators in the bureaucracy. This new regime of texts and associated practices was innovative in both format and content, creating a more integrated approach to pedagogy than methods of memorization usually associated with pre-modern Chinese education. Despite the absence of official standardization, printed and manuscript materials indicate that there was a high level of uniformity in Manchu language instruction. The emergence of this new regime of language acquisition was unique to the Qing in Chinese history and contributed a great measure to the regime's attempts to maintain distinctions between banner and non-banner subjects by allowing the empire to continue its official policy of bilingualism.

The Manchu language was significant to the Qing empire for two reasons. First, Manchu was politically mandated to be the official language of the empire. In modern scholarship over the last two decades, the Manchu language has been reconsidered as an essential part of the Qing order. Scholars have increasingly turned their attention to the Qing archives' millions of Manchu documents, some of which are translations from Chinese, but many of which are original. ${ }^{4}$ These central government documents have been used to argue that Manchu was a "security language,"5 which has been called into question in recent scholarship. Nonetheless, Manchu language materials have allowed

2. Most work on foreign language study during the Ming and Qing has neglected the role of Manchu language learning. For an overview of the materials used by translators see Norman Wild, “Materials for the Study of the Ssǔ I Kuan 四夷(譯)館 (Bureau of Translators)," Bulletin of the School of Oriental and African Studies 11, no. 3 (1945): 617-40.

3. In this article I use "bannermen" according to the umbrella definition inclusive of Mongol, Manchu, and Han banners proposed in Liu Xiaomeng 刘小萌, Qing dai Beijing qiren shehui 清代北京旗人社会 (Beijing: Zhongguo shehui kexue chuban she, 2008).

4. Mark C. Elliott, "The Manchu-Language Archives of the Qing Dynasty and the Origins of the Palace Memorial System," Late Imperial China 22, no. 1 (2001): 1-70.

5. Pamela Kyle Crossley and Evelyn S. Rawski, "A Profile of The Manchu Language in Ch'ing History," Harvard Journal of Asiatic Studies 53, no. 1 (1993): 70. 
us to radically reimagine Qing governance of its Inner Asian domains. ${ }^{6}$ Second, the language was also an important part of Manchu identity. Emperors continually remonstrated with their Manchu subjects to maintain their language skills so as not to forget the Manchu way of their ancestry. ${ }^{7}$ As both Mark C. Elliott and Pamela Kyle Crossley have argued, maintaining a distinct Manchu identity was an essential component of Qing statecraft. ${ }^{8}$ The continued bureaucratic use of Manchu, as well as its importance to the construction of the "ideal" frugal and martial Manchu man, testifies to the centrality of Manchu language to the regime's unique vision of empire, a vision that relied on the maintenance of a differentiated conquest elite. ${ }^{9}$

Despite the language's importance during the high Qing, the significance of Manchu language during the late Qing was overlooked by scholars prior to the rise of "New Qing History." This is undoubtedly because, as Edward Rhoads has noted, many late Qing bannermen no longer spoke or used Manchu. ${ }^{10}$ Despite their perceived monolingualism, however, the popularity of Manchu textbooks seems to indicate that bannermen were still studying the Manchu language. Through the act of studying the language, they were engaged in a different form of cultural reproduction than their non-banner peers.

In order to demonstrate the significance of Manchu language learning for the bannermen, this paper consists of three parts. The first section of the paper reviews some key aspects related to the institutionalization of Manchu language education through the translation examination system and state school system in the first half of the Qing period. Section two describes the initial innovation and development of Manchu language textbooks, the numerical, social, and geographical expansion of which occurred in parallel with the regular implementation of the translation examination. The final section turns away from the prescriptive features of textbooks and institutions and uses a number of unappreciated student notebooks and other pedagogical genres from the nineteenth century in order to reconstruct aspects of the experience of Manchu language learning. When considered together, these three aspects of Manchu language education—institutions, textbooks, and students' materials—radically expand our view

6. For a powerful recent example, see: Max Oidtmann, Forging the Golden Urn: The Qing Empire and the Politics of Reincarnation in Tibet (New York: Columbia University Press, 2018).

7. The most detailed treatment of the Manchu language and its importance to maintaining Manchu identity can be found in: Mark C. Elliott, The Manchu Way: The Eight Banners and Ethnic Identity in Late Imperial China (Stanford, Calif.: Stanford University Press, 2001). A brief overview of Manchu in the Qing government is given in Crossley and Rawski, "A Profile of The Manchu Language in Ch'ing History," 70. A recent article outlining the importance of translation and Manchu language education is Yeh Kao-shu 葉高樹, “Qingchao de qixue yu qiren de fanyi jiaoyu” 清朝的旗學與旗人的繙譯教 育, Taiwan Shida lishi xuebao, no. 48 (2012): 71-154. David Porter has recently done a great deal of work complicating our understanding of Manchu ethnicity and language learning. See: David Porter, "Bannermen As Translators: Manchu Language Education in the Hanjun Banners," Late Imperial China 40, no. 2 (2019): 1-43.

8. See Elliott, The Manchu Way, and Yeh Kao-shu, "Qingchao de qixue." See also Pamela K. Crossley, A Translucent Mirror: History and Identity in Qing Imperial Ideology (Berkeley: University of California Press, 1999).

9. The ideal Manchu qualities promoted by the court are fully detailed in Elliott, The Manchu Way.

10. Edward J. M. Rhoads, Manchus and Han: Ethnic Relations and Political Power in Late Qing and Early Republican China, 1861-1928 (Seattle: University of Washington Press, 2000). 
of the role Manchu language education played during the Qing. They illustrate the rise of new approaches to language acquisition and the ways in which the ruling elites' attempts to construct empire both influenced and were resisted through the everyday learning and readings practices of their bannermen subjects.

\section{Educational Reforms}

The creation of the Manchu script was one of the alleged achievements of Nurhaci, the founder of the early Manchu state. ${ }^{11}$ Shortly after the invention of the script, Nurhaci undertook the reorganization of northeastern peoples into hybrid social-military units called banners (Ma. güsa, Ch. $q i$ 旗) by no later than 1601. Jurchens were enrolled in banners, and their companies exerted a great deal of control over their lives, undermining earlier loyalties. The banners provided the bannermen their salaries, decided who could marry whom, and determined where one lived. By 1615, there were eight Jurchen banners in which every Jurchen under Nurhaci's authority was enrolled. As the state expanded, the population became more diverse. In 1635 the eight Mongol banners were established, followed shortly by banners for the Chinese. ${ }^{12}$

After the Manchu invasion of China in 1644, Manchu, Mongol, and Chinese banner troops were deployed throughout the empire and stationed in garrisons. A generation or two after the conquest, Manchu language loss became a reality for many banner families. The Korean emissary Kim Ch'ang-ŏp 金昌業 (1658-1721) noted in Beijing in 1712 that

Qing people (Ch'ŏng'in 清人) are all able to speak the Han language, and Han people (Han'in 漢人) are unable to speak the Qing language. It is not that they are "unable," only that they do not enjoy doing it ... [Therefore,] in the streets and alleys the Manchus and Han all use the Han language. Owing to this, youths born in the future won't be able to speak the Qing language ...

\section{淸人皆能漢語。而漢人不能爲淸語。非不能也。不樂爲也 ... 閭巷則滿漢皆用漢語。 以此淸人後生少兒。多不能通淸語。13}

The decline of the Manchu language had already become a matter of official concern in the late Kangxi and early Yongzheng period. First, Manchu translation was a regular

11. There was no "Manchu" script until the northeastern groups consisting primarily of Jurchens were renamed "Manchu" by Hong Taiji in 1635: Pamela Kyle Crossley, A Translucent Mirror, 3; Elliott, The Manchu Way, 71.

12. Elliott, The Manchu Way, 59.

13. Kim Ch'ang-ŏp 金昌業, Yŏnhaeng ilgi 燕行日記, vol. 31, Yŏnhaengnok chŏnjip (Seoul: Tongguk Taehakkyo ch’ulp’anbu, 2001), 289. Kim and many other Korean observers frequently refer to all bannermen as "Qing people." 
aspect of bureaucratic procedure. Since many of the higher positions within the Six Boards were shared between a Chinese and a Manchu official, day-to-day functions of the bureaucratic diarchy initially relied on translations, and most materials handled by the Boards were copied and translated into both Chinese and Manchu. ${ }^{14}$ This meant that the vast majority of routine memorials entering the central administration first went to the translation offices to be rendered into either Manchu or Chinese (depending on the language of the original), before returning to the normal processing channels. ${ }^{15}$ The massive volumes of paperwork required a proverbial army of translators known as bithesi to keep up with the demand for translations. For the duration of the Qing Dynasty, the court relied on Manchu language education to supply trained translators.

In addition, Qing emperors viewed Manchu language skills as an essential aspect of their heritage and the heritage of most bannermen. After the Qing dynasty was declared in 1636, Manchu (Ma. manju gisun) was referred to as the "Qing language" (Qingyu 清 語), “the Manchurian language," (Manzhou yu 滿洲語), or “national language” (guoyu 國語). ${ }^{16}$ The Yongzheng emperor, following his predecessors, made a strongly worded summary of the place of Manchu language in banner society:

[According to the] old system of the Manchus, studying Manchu [lit. Qing language] is of the utmost import. Now, we observe that those who have been selected as palace guards have abandoned Manchu, which they should be studying, and instead tease one another in the Han language. This is not at all appropriate.

\section{滿洲舊制。最重學習清語。近見挑選之侍衛 護軍等。棄其應習之清語反以漢語互相 戲 謔。甚屬不合。17}

For the Qing emperors, knowledge of the Manchu language, together with skills in mounted and standing archery, was essential to Manchu and banner identity. To prevent the acculturation of their banner subjects, the court actively promoted these values, especially through the establishment of banner schools.

During the Shunzhi (1644-61) and Kangxi (1661-1722) periods, most official schools for bannermen were open only to a small coterie of handpicked students from

14. Beatrice S. Bartlett, Monarchs and Ministers: The Grand Council in Mid-Ching China, 1723-1820 (Berkeley: University of California Press, 1991), 35-36. For information on the movement of memorials, see: Silas H. L. Wu, Communication and Imperial Control in China Evolution of the Palace Memorial System, 1693-1735 (Cambridge, Mass.: Harvard University Press, 1970), 27-33. On translation see examinations, see: Porter, "Bannermen as Translators."

15. See Mårten Söderblom Saarela, "Linguistic Compartmentalization and the Palace Memorial System in the Eighteenth Century," Late Imperial China 41, no. 2 (2020): 131-79.

16. On the founding of the dynasty and the Manchu people see Elliott, Manchu Way, 46-47. On the Qing language see 291. All of these Chinese names for Manchu were translated as manju gisun in Manchu.

17. Yongzheng Emperor, Shangyu baqi 上諭八旗 (Beijing: Wuying dian, 1741), YZ6:2a-b, dated YZ6.1.29. 
the banners or members of the imperial lineage. ${ }^{18}$ To combat the loss of Manchu proficiency, the Yongzheng emperor began to institutionalize Manchu language education. As David Porter has noted, many of these schools were initially for Han bannermen. ${ }^{19}$ In an edict early in his reign dated October 10, 1724, the emperor commanded the establishment of a school at each banner's military practice ground. He commanded every banner to select two teachers to instruct banner youths in archery and Manchu. The Yongzheng reign initiated a movement towards the localization of schools within the Beijing banners. Moreover, education expanded to embrace a wider cross-section of the banner population, including the first banner academy for Mongolian students. ${ }^{20}$

Yongzheng's concern with Manchu language loss would be the most likely explanation for the official establishment of what would become an institutional hallmark of the Qing regime: the translation examination system. The translation examinations were initiated under the Kangxi emperor, but throughout his reign they occurred sporadically and were largely ad hoc. ${ }^{21}$ The Yongzheng emperor established the examinations on a regular triennial schedule during the first year of his reign. ${ }^{22}$ An edict on May 16, 1723 stated:

An examination for [testing the] the translation skills of the bannermen of the Manchu Eight Banners shall be established. Henceforth, Manchus and Mongols who are capable in translation shall be tested at the level of xiucai twice every three years; the level of juren once every three years; and the level of jinshi once every three years.

\section{八旗滿洲人等、設繙譯技勇之科.嗣後將滿洲蒙古,能繙譯者.三年之內,考取秀才二 次.舉人一次.進士 一次. 23}

Despite official desire to test translation examination candidates at the national level, there were no higher-level examinations during the Yongzheng reign. Translation candidates were tested locally, and the juren degree was the highest any examinee earned. ${ }^{24}$

18. Crossley, A Translucent Mirror, 359. The most detailed account of education policies in English is Pamela Kyle Crossley, "Manchu Education," in Education and Society in Late Imperial China, 1600-1900, ed. Benjamin A. Elman and Alexander Woodside (Berkeley: University of California Press, 1994), 340-78.

19. Porter, "Bannermen as Translators."

20. Yeh Kao-shu 葉高樹, Qingchao qianqi de wenhua zhengce 清朝前期的文化政策 (Banqiao: Daoxiang chuban she, 2002). For an expansion on this see his article cited above, Yeh Kao-shu 葉高樹, “Qingchao de qixue yu qiren de fanyi jiaoyu” 清朝的旗學與旗人的繙譯教育. I thank Macabe Keliher for these references.

21. Wang Li 王麗, “Qingdai fanyi ke shulun” 清代翻譯科述論, Liaoning Daxue xuebao 29, no. 4 (2001): 40-43; Zou Changqing 鄒長清, “Qingdai fanyi ke kaolun” 清代翻譯科考論, Shijiazhuang Xueyuan xuebao 14, no. 5 (2012): 23-33.

22. Here I follow Zou Changqing, "Qingdai fanyi ke kaolun." Later editions of the Daqing huidian 大清會典 date the exams to the Shunzhi reign, but there is no other evidence that they were anything more than occasional. Also see Elliott, The Manchu Way, 204, 301.

23. “Ming Qing Shilu” 明清實錄, YZ 1.4.xinyou (May 16, 1723), accessed August 21, 2016, http://sillok.history.go.kr/mc/ searchResultList.do.

24. Wang Li, "Qingdai fanyi ke shulun," 41; Zhou Changqing, "Qingdai fanyi ke kaolun," 23-24. 
While the early Yongzheng translation examinations focused exclusively on translation between Manchu and Chinese, Mongolian language loss among the Mongol bannermen also concerned the court. In 1731, the emperor ordered the establishment of the Mongolian translation examination. Yongzheng noted that

\begin{abstract}
Mongolian bannermen who are able to speak Mongolian and translate Mongolian writing are few. Over time they will gradually come to abandon it. It is fitting that Mongolian bannermen be tested in translation in accord with the statute for testing Manchu translators for the ranks of shengyuan, juren, and jinshi.

\section{蒙古旗分人，能蒙古語言、繙譯者甚少,沿習日久 . . . 必漸至廢棄.宜合蒙古旗下人 亦照考試滿洲繙譯生員舉人進士之例。25}

The importance of the institution of regular examinations in Manchu translation should not be underestimated. Benjamin Elman has argued that the Chinese examination system was one of the major means through which ruling dynasties legitimated their rule. ${ }^{26}$ The examination system limited participation in government to the few educated elite individuals who could master a large corpus of materials based on the language of officialdom. In doing so, they stratified society by limiting engagement with the government to those with sufficient cultural and financial capital, all the while promoting meritocratic ideals. However, examinations also incorporated the educated elite into the state by allowing a large number of individuals to engage the state directly through the test-taking process, a process which allowed for intellectual debates and criticisms of policy. ${ }^{27}$

The translation examinations likewise provided the bannermen with an alternative way to engage the state even when they were not guaranteed a hereditary salaried banner position. ${ }^{28}$ At the same time, the translation examinations reinforced state expectations of bannermen's mastery of basic skills in archery and Manchu language by limiting advancement to those who were educated according to the court's ideals. ${ }^{29}$ Furthermore, the establishment of a separate examination system for banner students was a product of Qing preference for maintaining separation between the bannermen and the Han majority. While bannermen could and did pass the normal examinations, the translation examination was much easier for most of them. The importance of this system continued to grow

25. Zhan Hongmou 詹鴻謨, ed., Qinding kechang tiaoli 欽定科場條例 (Beijing: Neiwufu, 1887), 56.6b. For more details on this edict and the political context, see: Yeh Kao-shu 葉高樹, “Qingchao de fanyi kekao zhidu” 清朝的繙譯科考制度, Taiwan Shida lishi xuebao, no. 49 (2013): 58.

26. This argument is articulated throughout Benjamin A. Elman, Civil Examinations and Meritocracy in Late Imperial China (Cambridge, Mass.: Harvard University Press, 2013).

27. See Elman, Civil Examinations. 277-79.

28. On the crisis over the lack of inheritable positions, see Elliott, The Manchu Way, 305-44.

29. Elliott, The Manchu Way, 275-304. 
throughout the eighteenth and nineteenth centuries, and many important bannermen officials began their careers after passing the translation examination. ${ }^{30}$

During the Qianlong reign (1735-96), such educational policies grew in scope. The expansion of official schools outside of Beijing brought official education to the previously neglected garrisons. In 1772, the Liangguang Governor-General Li Shiyao 李侍 堯 (d. 1788) received permission to establish state schools (guanxue) within the banner garrison at Guangzhou. Talented students who were able to speak Manchu were selected by company commanders, and their education was funded by the state. ${ }^{31}$ In 1780, Chang-tai, the commander of the right wing of the Mongolian banners at Jingzhou, requested that "each banner establish a Manchu and Chinese official school and charitable school." 32 By the end of the Qianlong reign, Manchu language education was a permanent feature of the Qing pedagogical landscape. This official emphasis on the importance of the Manchu language stimulated the emergence of pedagogical genres for the study of Manchu.

\section{Textbooks}

The expansion of the school system and the translation examinations was accompanied by the rise of new Manchu language pedagogical genres. ${ }^{33}$ Evelyn Rawski has estimated that roughly 25\% of engraved material in Manchu was related to language learning. ${ }^{34}$ The wide array of Manchu language learning materials available on the Qing book market illustrates the ways in which imperial incentives rewarding Manchu competency drove market demands for genres devoted to Manchu language study. One grammar book, Qingwen jiezi 清文接字, (A Manchu Grammar), explicitly linked Manchu language study to the institution of the translation examination by noting that the Qing state "had emphasized the national language and established the translation examination . . ." (Gurun i bithe be obuhabi. Ubaliyabure be simnere be ilbufi . . .) ${ }^{35}$

30. The author is currently planning a future project on translation degree holders and bureaucratic advancement. David Porter is also working on early translation examinations.

31. Changshan 長善, ed., Zhu Yue baqi zhi 驻粤八旗志 (Shenyang: Liaoning Daxue chubanshe, [1879] 1990), 98.

32. Xi-yuan 希元, ed., Jingzhou zhufang baqi zhi 荆州驻防八旗志 (Shenyang: Liaoning Daxue chubanshe, [1879] 1990), 106.

33. For general overviews of Manchu pedagogical materials, see Tatjana A. Pang, "Mandschurische Sprachführer aus der Sammlung der Leningrader Abteilung des Orientalischen Instituts der Akademie der Wissenschaften," Central Asiatic Journal 32, no. 1/2 (1988): 91-97; Zhao Lingzhi 赵令志, “Qingdai Man-Han hebi zicishu jiqi zuoyong tanxi” 清代满汉 合璧字辞书及其作用探析, Manyu yanjiu 滿語研究, no. 2 (2009): 65-70. For an introduction to Manchu lexicographical materials, see Chunhua 春花, Qingdai Man Meng wen cidian yanjiu 清代满蒙文词典研究 (Shenyang: Liaoning minzu chubanshe, 2008); Mårten Söderblom Saarela, "Manchu and the Study of Language in China (1607-1911)" (PhD diss., Princeton University, 2015).

34. Evelyn S. Rawski, "Qing Publishing in Non-Han Languages," in Printing and Book Culture in Late Imperial China, ed. Cynthia Brokaw (Berkeley: University of California Press, 2005), 304-25.

35. Song Luofen 嵩洛峰, Xinyu Qingwen jiezi 新語清文接字 (Beijing: Fanyi shufang, 1898), xu:1a. 
However, despite the ways in which these materials appear to have emerged in response to state expectations for Manchu language competency, their model dialogues did not reflect the idealized figure of the frugal, martial, and forthright Manchu that the emperors imagined. Bannermen learned Manchu, but the model conversationalists in their textbooks were like them, urbanized and enjoying the fruits of Manchu conquest. The textbooks show us that they were more interested in discussing social occasions than the "Manchu Way." The Manchu that students learned reflected their realities, and these were the very realities that the court saw as heralding the end of Manchu traditions. ${ }^{36}$ Manchu language textbooks and associated pedagogical materials emerged as genres in which the ideal Manchu attributes promoted by the court were contested and reconstructed to suit the reality of the highly social, urbanized milieu of Manchu language learners.

Manchu textbooks differed from most educational materials available in late imperial China. The Chinese book market was flooded with didactic primers for children's education. These textbooks were "created, transmitted, or received as a text designed to teach, instruct, advise, edify, inculcate morals, or modify and regulate behaviour." 37 The combination of morality instruction and literacy was the core of Chinese education, and as Bai Limin notes, they underwent, there was minimal change in the genre through the late imperial period. ${ }^{38}$ Didactic works such as the Classic of Filial Piety or The Three Character Classic introduced children to the fundamentals of Chinese cosmology. The intention of these works was both to impart basic literacy and shape readers into moral beings.

In addition to the heavily didactic textbooks used in early literacy education, other sorts of pedagogical texts were common in the Qing. Students of Chinese medicine used a number of texts early in their training. A common text, the Yaoxing fu 藥性賦 (Rhymes on the Nature of Drugs), introduced the basic uses of common pharmaceuticals. ${ }^{39}$ Consisting entirely of short phrases, the text, like other primers, was meant to be memorized in its entirety. Other manuals instructed students in business and travel, but they were mostly intended as self-help books for autodidacts. ${ }^{40}$ Some concrete skills were also introduced with textbooks. A manual printed in Sibao taught students how to use

36. Elliott, The Manchu Way, 275-304.

37. Juanita Feros Ruys, "Introduction: Approaches to Didactic Literature-Meaning, Intent, Audience, Social Effect," in What Nature Does Not Teach: Didactic Literature in the Medieval and Early-Modern Periods, ed. Juanita Feros Ruys (Turnhout: Brepols Publishers, 2008), 5.

38. For an overview, see: Limin Bai, Shaping the Ideal Child: Children and Their Primers in Late Imperial China (Hong Kong: The Chinese University Press, 2005). For more on early education, see: Li Yu, "Character Recognition: A New Method of Learning to Read in Late Imperial China," Late Imperial China 33, no. 2 (2012): 1-39.

39. Angela Ki Che Leung, "Medical Instruction and Popularization in Ming-Qing China," Late Imperial China 24, no. 1 (2003): 130-52.

40. For a full description of merchant manuals and their impact Richard John Lufrano, Honorable Merchants: Commerce and Self-Cultivation in Late Imperial China, Studies of the East Asian Institute (Honolulu: University of Hawai'i Press, 1997). 
an abacus for accounting. It was one of many manuals designed to introduce technical subjects to novice students. ${ }^{41}$

Like abacus manuals, Manchu textbooks were intended to impart practical skills. But, as Hansun Hsiung describes of more modern textbooks, they presented Manchu as a "discrete discipline, a systematized body of knowledge possessing its own autonomous theory and method." They were considerably more sophisticated than technical manuals. Manchu textbooks became a genre like many modern genres in that they made "epistemic claim[s] (science, discipline), while also being tailored for use in specific social environments and their associated pedagogical techniques (classroom instruction)." 42 These language primers were the product of a model of education not seen in other pre-modern Chinese educational materials. They taught the technical skills of literacy and second language competency with an elaborate set of pedagogical practices in mind.

\section{Shen Qiliang}

The Chinese scholar Shen Qiliang 沈啓亮 composed the earliest surviving Manchu textbook. Shen was born sometime around 1645, and his family was greatly affected by the violence of the Ming-Qing conflict. The infamous warlord Zhang Xianzhong killed his grandfather while he was serving as a magistrate in Sichuan, and his father, a Qing colonel, died when Zheng Chenggong sacked Zhenjiang. Shen also served in the Qing military, but he was a self-professed bookworm. In 1677, he moved to the Bordered Yellow Banner section of Beijing's inner city and began to study Manchu with an instructor. His teacher taught him to read and write the language using two writing primers, The Twelve Heads of Manchu Letters (shi'er zitou 十二字頭) and Forty Heads (dehi uju). ${ }^{43}$ Although Shen found the Manchu script relatively easy to master, the dearth of language learning materials oriented toward the study of grammar and practical conversation inspired him to compose his own textbook, one which structured language acquisition in a groundbreaking manner. ${ }^{44}$

The majority of surviving materials for language study from the Ming and the early

41. Cynthia Joanne Brokaw, Commerce in Culture: The Sibao Book Trade in the Qing and Republican Periods, Harvard East Asian Monographs 280 (Cambridge, Mass.: Harvard University Asia Center, 2007), 342-44.

42. Hansun Hsiung, "Book-keeping Moderniz'd: The Textbook from Mimesis to Method" (Unpublished seminar paper, Harvard University, 2011). Cited with author's permission.

43. Biographical detail is drawn from Kanda Nobuo, "Shen Ch'i-liang and His Works on the Manchu Language," in Proceedings of the Third East Asian Altaistic Conference, eds. Ch'en Chieh-hsien and Sechin Jagchid (Taipei: National Taiwan University, 1969), 130-31. Kanda draws most of this information from the preface of Shen Qiliang's Qingshu zhinan, discussed below.

44. For more on Shen, see: Mårten Söderblom Saarela, "Shier zitou jizhu (Collected Notes on the Twelve Heads): A Recently Discovered Work by Shen Qiliang," Saksaha: A Journal of Manchu Studies 12 (2014): 9-31. 
Chosŏn translation bureaus present languages lexicographically-as lists of glossed words for study. ${ }^{45}$ A few exception exist, such as the Korean conversation manual Nogŏltae 老乞大 (The Old Northerner), which, like lexicons, was apparently memorized. ${ }^{46}$ The lexicographical approach, while the most intuitive approach to language acquisition, is also the least sophisticated. Early modern East Asian foreign language acquisition prior to the Qing was the preserve of either hereditary language learners or language specialists who relied primarily on the rote memorization of lists and dialogues. Grammar was never explained. ${ }^{47}$ Before Shen, there were no attempts to create accessible curricula usable by more than professional households or an elite coterie. Shen's Guide to Qing Writing (Qingshu zhinan 清書指南) eschewed the lexicographical approach in favor of a curriculum that integrated grammar, conversation, and reading. His textbook was meant to be a complete and coherent introduction to the subject for use in a pedagogical environment. ${ }^{48}$

The Guide is divided into three chapters, two of which reflect Shen's innovative approach to Manchu language acquisition. The first chapter reproduces The Twelve Heads of Manchu Letters (shier zitou 十二字頭) and dehi uju (Forty heads). From Shen's preface, we know that these materials existed prior to his arrival in Beijing. This shows that prior to Shen's textbook there were certain pedagogical genres used by the Manchu speaking community, and they appear to have been introductions to the script.

The other two chapters of Shen's textbook are original. The second chapter preserves the earliest existing Manchu model dialogues. In the section "An Explanation of the Guide to Qing Writing" (Qing shu zhinan shuo 清書指南說), he testifies to this chapter's innovative nature through this defense of his methodology:

[The section on the] miscellaneous speech of the Manchus, while not reaching one ten-thousandth of the [possibilities for conversation], still has real benefit

45. See Wild, "Materials for the Study of the Ssǔ I Kuan." David Brophy has an interesting discussion of translingual practices in Qing Xinjiang. He also introduces some aspects of the translation bureau before and during the Qing: David Brophy, "The Junghar Mongol Legacy and the Language of Loyalty in Qing Xinjiang," Harvard Journal of Asiatic Studies 73, no. 2 (2013): 231-58.

46. Svetlana R. K. Dyer, Grammatical Analysis of the Lao Ch'i-Ta: With an English Translation of the Chinese Text (Canberra: Faculty of Asian Studies, Australian National University, 1983).

47. Much work has been done on pre-modern foreign language study in East Asia. The Manchu textbooks produced in China appear to be the first books to incorporate conversation and grammar into the same text. For information on foreign language pedagogy in Japan and Korea, see: Henk De Groot, "The Study of the Dutch Language in Japan During Its Period of National Isolation (ca. 1641-1868)" (PhD diss., University of Canterbury, 2005). See also Jiro Numata, “The Introduction of Dutch Language," Monumenta Nipponica 19, no. 3/4 (1964): 243-53; Ogura Shinpei 小倉進平, Chōsengogaku shi 朝鮮語学史 (Tōkyō: Tōkō shoin, 1964, revised edition); Lin Dongxi 林東錫, “Chaoxian yixue kao” 朝鮮 譯學考 (PhD diss., National Taiwan Normal University, 1982). See also Sixiang Wang, “Chosŏn's Office of Interpreters: The Apt Response and the Knowledge Culture of Diplomacy," Journal for the History of Knowledge 1, no. 1 (2020): 1-15. English-language pedagogical materials from Canton are described in Kingsley Bolton, Chinese Englishes: A Sociolinguistic History (Cambridge: Cambridge University Press, 2003).

48. The best complete description of this work in English is found in: Mårten Söderblom Saarela, The Early Modern Travels of Manchu: A Script and Its Study in East Asia and Europe (Philadelphia: University of Pennsylvania Press, 2020). 
for the student. Some may say, "This is all vulgar speech" and so set it aside. I say to them, "It is vulgar speech. Truly vulgar speech. If a Han person is unable to say these vulgar words, then when they are hungry they will not be able to say they want food, and when they are thirsty they will not be able to say that they want hot water to drink. Wouldn't they then be called dumb?" Thus, those who study Qing texts will find that their efforts proceed from studying speech. Becoming familiar and conversant in Manchu speech is truly the ultimate basis for translating texts. If they are not familiar with Manchu speech, then even if they are good at translating, in the end their results will be rough.

\section{滿洲雜話。雖未及萬分之一。然於學者實有裨益。有人言日。此係粗話。姑且置之也。 余 $\square$ 之日。粗話。眞粗話也○若漢人不能説粗話。使饑者不得説要 飯吃。渇者不得説 要湯飲。不名之爲啞吧乎。故凡學清書者。務必隨帶學話。使滿話繩熟。實爲翻書之 最。如滿話不熟。翻書雖善。終爲涉滯。49}

Shen's defense of these everyday conversations shows that he anticipated a critique of his methodology, which contradicted the literary standards of Chinese scholars. His decision to include colloquial conversations on everyday topics went against the morally didactic model of most other textbooks.

The conversations in the textbook are written in Manchu without Chinese glosses. They begin with the basics of name and banner association:

Which banner do you belong to? Si ya gūsaningge

The Bordered Yellow Banner. Kubuhe suwayaningge.

Whose niru [unit] are you in? Si wei nirui

I'm in this niru. Tere niruningge. ${ }^{50}$

These seemingly simple questions were essential to banner identity. Answers would immediately tell your conversation partner where you lived within Beijing, as well as your family status, and provide the basis for further conversation.

Throughout the second chapter, the dialogues never stray far from questions and answers about social status, family, and casual encounters-all topics that served to locate the speakers in banner society. As unremarkable as these dialogues may seem, they were wholly unprecedented. Manchu speakers who learned the script during the early Qing did not require examples of colloquial conversation. Shen provided them as

49. Shen Qiliang 沈啓亮, Qingshu zhinan 清書指南 (microfilm of the blockprint edition held at Tenri University, preface dated 1682), Chinese appendix, 4a-b. I am especially grateful to the unrivaled generosity of Mårten Söderblom Saarela for sharing his scan of this text with me.

50. Shen Qiliang, Qingshu zhinan, 2.1a. 
models for second language learners, probably Han Chinese who were working closely with Manchu officials in Beijing. As such, the conversations reflect the quotidian realities of life in Beijing.

The third chapter of Shen's textbook explains Manchu grammar. ${ }^{51}$ Shen, who understood Chinese linguistic categories, analyzed the radically different structure of Manchu according to preexisting Chinese grammatical terminology. Shen labeled Manchu conjugations and particles as “empty words” ( $x u z i$ 虛字), a term for all grammatical components in a language. ${ }^{52}$ With this linguistic category in hand, he rendered the alien structure of Manchu into more familiar linguistic patterns.

A brief example of his explanation of the accusative particle -be should serve to illustrate his innovative application of these categories:

As an empty word, it is the Chinese word jiang (object marker) and ba (to take up). As a full word (i.e., a substantive), it is "we," "bird seed," "bait," or "track."53 Thus, to say, "take this thing for something," one says ere jaka be. [To say] "take this person for something," one says ere niyalma be.

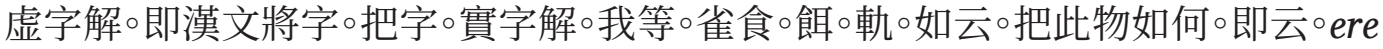
jaka be. 將此人如何。即云 $\circ$ ere niyalma be..$^{54}$

To Shen's contemporaries, this explanation of -be would have immediately clarified its function as an accusative particle. ${ }^{55}$ While Chinese speakers would have been surprised to see the accusative -be follow the noun, its frequent recurrence in the model dialogues would have helped readers further their understanding of the particle's function as a post-position. Despite the fact that Chinese linguistics lacked an equivalent for the term "accusative," Shen's textbook illustrates that such linguistic concepts could be easily explained through reference to Chinese words and Manchu examples.

51. For a detailed explanation of the development of grammatical explanations in Manchu texts, see: Takashi Takekoshi, "Grammatical Descriptions in Manchu Grammar Books from the Qing Dynasty," Histoire Epistémologie Langage 41, no. 1 (2019): 39-55.

52. For a brief introduction to the development of xuci see Chen Zhiming 陳志明, “Gu hanyu xuci yanjiu shi shulüe” 古汉语 虚词研究史述略, Shanxi Daxue xuebao, no. 2 (1994): 86-88. A brief survey of this literature has revealed a rather large lacuna in studies relating to the development of xuci prior to the Qing. The Qing, on the other hand, is marked as "the golden age" of linguistic studies. The seminal texts in this golden age postdate Shen's textbook, clearly demonstrating that grammatical categories were being used for practical purposes well before the kaozheng boom of the eighteenth century.

53. I have been unable to find be as an equivalent to gui in any Manchu-Chinese dictionaries.

54. Shen Qiliang, Qingshu zhinan, 3:1a.

55. Liliya M. Gorelova, Manchu Grammar (Leiden: Brill, 2002), 166. 
Textbooks in the Eighteenth Century

After the engraving of the Guide to Qing Writing in 1682, no other comprehensive textbooks appeared for approximately fifty years. While the textbook was much reprinted along with Shen's Manchu-Chinese dictionary, it was of limited interest, and oriented towards a specialist audience of Chinese Manchu-language learners. ${ }^{56}$ In the early Qing, the banner populations still spoke Manchu, and thus had no need for Shen's language learning materials. Some materials, such as a Manchu and Chinese bilingual edition of the Three Character Classic, were engraved, but they were not part of an established language learning curriculum. ${ }^{57}$ In the early eighteenth century, a greater diversity of Manchu primary education materials began to circulate, but most were not for second language learners. ${ }^{58}$

The next comprehensive textbook to appear was targeted towards bannermen and was written in the Hangzhou garrison before being printed in Beijing. ${ }^{59}$ The four-chapter Cing wen kimeng, or The Manchu Preceptor (Qing wen qimeng 清文啟蒙) was engraved in $1730 .{ }^{60}$ Following the Qing invasion of China in 1644, the Manchu government established banner garrisons throughout the empire in major cities, including Xi'an, Hangzhou, and Guangzhou. With the addition of their own walls, the garrisons became cities within cities. Ideally, garrison populations remained segregated from civilian Chinese populations, but this proved impossible in practice. ${ }^{61}$ The inevitable mixing between populations that occurred resulted in rapid language loss amongst some Manchu garrison populations.

When The Manchu Preceptor was engraved in 1730, the court was increasingly emphasizing the importance of Manchu fluency amongst bannermen. The Yongzheng emperor had established the translation examinations only six years earlier. Preceptor was designed for an increasingly Sinophone banner audience, so as to prepare them for both the translation examinations and the court's expectations for Manchu competency. The textbook is the first example of a Manchu authored textbook that responded to new market demands for Manchu pedagogical materials.

\footnotetext{
56. On his dictionary, see Chunhua, Qingdai Man-Meng.

57. Zhao Lingzhi, "Qingdai Man-Han," 65-70.

58. Zhao Lingzhi, "Qingdai Man-Han."

59. Some earlier texts were available, but they do not seem as developed as Cing wen. For more detail, see: Crossley and Rawski, "Profile," 85-87; and Mark C. Elliott and James E. Bosson, "Highlights of the Manchu-Mongol Collection in the Harvard-Yenching Library," in Treasures of the Yenching: Seventy-Fifth Anniversary of the Harvard-Yenching Library Exhibition Catalogue, ed. Patrick Hanan (Cambridge, Mass.: Harvard-Yenching Library, 2003), 83.

60. Wu-ge 舞格, Cingwen kimeng bithe | Qingwen qimeng 清文啟蒙 (Beijing: Jingdu yinghua tan, 1730), xu:3a. 1730 is the date of the preface. With regard to the translation: A "preceptor" refers to a specific person, as in an instructor, whereas kimeng ( $<$ Ch. qimeng 啓蒙) refers to the action or concept of instruction or initiation in general.

61. Elliott, The Manchu Way, 105-32.
} 
This shift in audience from the Chinese to the banner heritage student, including the Chinese banners, is attested in the preface to Preceptor. The author of the textbook, Wu-ge, was a private family tutor educating banner youth. The preface by his friend Cheng Mingyuan 程明遠 praises his pedagogy, saying, “I have seen my friend . . . instructing youth, who, although of very limited capacities, were able to read and write before they had been but a month under tuition . . ."62 Wu-ge eschewed rote memorization of moral treatises in favor of models that he was worried were too "crude" (Ma. calgari, Ch. bi 鄙) for engraving. ${ }^{63}$ Like the earlier textbook by Shen Qiliang, Wu-ge's text initiated students by means of a colloquial approach to Manchu. In describing this methodology, both authors note that their emphasis on the colloquial may be "rough, vulgar, or crude" (translated by the Manchu muwa), but despite any objections, their approach to language acquisition achieved real results, and their emphasis on this method derived authority from their practical experiences as both language learners and teachers.

After its engraving, The Manchu Preceptor became a source inspiring later pedagogical genres. In terms of content, Preceptor closely follows the model established by Shen's Guide to Qing Writing. The first chapter teaches pronunciation proceeding from the basic vowels $a, e, i, o, u, \bar{u}$, into the more complex rules of the script. The second chapter consists entirely of short model dialogues and their accompanying translations into Chinese. These model dialogues were perhaps intended for memorization. ${ }^{64}$ The dialogues in Preceptor cover a wide range of topics, from the mundane rules of being a polite guest to banner-specific experiences with education and the state. The third chapter consists of grammar rules, and the fourth chapter contains further orthography instruction as well as notes on commonly confused words.

Unlike the Guide, The Manchu Preceptor is entirely bilingual. Chinese literate students who used Preceptor did not need to rely on teachers or classmates for explanations. The textbook was intended as a complete curriculum, capable of living up to Cheng Mingyuan's promise of complete instruction in reading and writing in under a month. Another feature sets Preceptor apart from its predecessor: Whereas Shen's model dialogues tend to be relatively dry, Wu-ge's much longer selections cover much more interesting material. Dialogues in the book are satirical of Manchu education at that time-particularly thanks to Wu-ge's colloquial methodology.

62. The full text has been translated. See Alexander Wylie, Translation of the Ts'ing Wan K'e Mung, a Chinese Grammar of the Manchu Tartar Language: With Introductory Notes on Manchu Literature (Shanghai: London Mission Press, 1855), 1. His translation of the preface does not include the Manchu.

63. Wu-ge 舞格, Cingwen, xu:2b.

64. Wylie, Translation, lix-lx. 
"On this occasion does your teacher come? He comes. He certainly comes once a day. That being the case ... what kind of instruction does he give you? The instructions we receive from this one are all superficial common-place sayings." 65

ere ucuri suweni sefu kemuni jimbio akūn. jimbi. emu inenggi de urunakū emu mudan jimbi. tuttu oci . . . suweni ai jergi gisun tacibumbi. meni ere sefu i tacibuhangge gemu yasai juleri gisurere an i gisun.

這一向你們師傅還來不來。來。一日必定來一次。若是那們着 . . . 教你們些什麼話。 我們這個師傅教的都是眼面說的尋常話。

As this dialogue continues, the conversation goes on to criticize the teacher for not teaching the Four Books or the art of translation, and relying too much on unpolished or vulgar speech (muwa gisun).

Comedic sections making fun of teaching styles are supplemented by other sections that reflect on life in the banners. The frustrations of banner experience appears in a section on archery:

"I can perform foot archery but not horse archery. Why do you not learn horse archery? I have not learnt because I have no horse. Let's see you draw the bow. Yes. Aya! I cannot bend this bow."66

gabtame bahanambi. niyamniyame bahanakū. siainu niyamniayare be taciburakū. morin akū ofi. tacihakū. si beri tatame tuwa. ja. ara. ere beri i tebke be bi inu neime muterakū.

我射步箭不會射馬箭。你為什麼不學馬箭。因為沒有馬不曾學。你拉拉弓瞧。哦。啊 呀。這個弓的熱子我也開不開。

Upon failing to bend the bow, the teacher tells the student to quit and go read a book. This dialogue could serve as a metaphor for banner experience, since maintaining martial skills was a court demand that many bannermen failed to attain. Perhaps its humor explains why the book was reprinted numerous times across the Qing, becoming a boilerplate for Manchu language study. ${ }^{67}$ Manchus throughout the Qing would have

65. Modified from Wylie, Translation, 70-71; Wu-ge, Cingwen, 2.25a-b.

66. Modified from Wylie, Translation, 83; Wu-ge, Cingwen, 2.33a.

67. For a more detailed examination of the work, see Wylie, Translation. 
enjoyed learning dialogues that complained about impoverished relatives begging for handouts, Chinese festivals, and liars. ${ }^{68}$

The model dialogues in Preceptor contributed to the development of a sub-genre of conversation-cum-exercise manuals. These became some of the most popular references for study. Works such as Dehi meyen and Tanggū meyen, or Forty Exercises and One Hundred Exercises, were printed numerous times, beginning in the middle of the eighteenth century. ${ }^{69}$ These conversation books were printed primarily in Beijing, but they were also being engraved in the garrisons. ${ }^{70}$ These manuals provide a great deal of insight into the lives of typical bannermen and language learners. ${ }^{71}$ The dialogues are written to reflect useful hypothetical encounters, framing the expectations of the Manchu student. Unlike many of the primers used in a Confucian education, the authors of Manchu conversation manuals rarely seem to concern themselves with the "ideal student." This seems to be well reflected in the behavior of some of the Manchu students, who are frequently portrayed as mischievous.

The most successful successor of Preceptor was Essentials of the Manchu Language (Qingwen zhiyao 清文指要). Essentials incorporated phrases from One Hundred Exercises, and likewise contained one hundred examples of conversations in different contexts. After its initial engraving in 1789, there were at least five other editions of the textbook, including an 1818 version printed in Xi'an. ${ }^{72}$ The preface of Essentials details the changes in the status of Manchu language by the late Qianlong reign. The author, Fugiyūn (Fujun 富俊), a translation jinshi belonging the Mongolian Plain Yellow Banner, was one of the many Mongols active in Manchu language teaching and textbook compilation in late eighteenth- and early nineteenth-century Beijing. ${ }^{73}$

Fujun echoed imperial sentiments by arguing that "The Manchu language is the root of the Manchu people . . ." (manju gisun serengge manju halangga niyalmai fulehe . . .). ${ }^{74} \mathrm{He}$ proceeded to note that if someone who is a Manchu cannot speak their own language, then they will inevitably lose face and become a laughing stock. ${ }^{75}$ In

68. See Wylie, Translation, 113-15.

69. These works are described in Zhao Lingzhi, "Qingdai Man-Han"; and Tatiana Pang, "Mandschurische Sprachführer." Copies held by the Harvard-Yenching Library are discussed later in the paper.

70. Fujun 富俊, Xinkan Qingwen zhiyao 新刊清文指要 (Xi'an: Xi'an jiangjun shunei, 1818).

71. Manchu primers can be used for gaining insight into social conditions in banner life. As an example, see Yves Trachsel, "Substance Abuse Among Bannermen and Banner Self-Perception: An Analysis of Qing Language Primers," Saksaha: A Journal of Manchu Studies 15 (2018).

72. Liu Man 劉曼 and Zhang Meilan 張美蘭, “Qingdai zhuming de Man-Han shuangyu jiaocai Qingwen zhiyao (bai zhang) ji qi jiazhi” 清代著名的滿漢雙語教材《清文指要》(百章)及其價值, Haiwai huawen jiaoyu, 62, no. 1 (2012): 89-94.

73. More on Mongolian students of Manchu will be seen in the next section.

74. Fujun, Qingwen zhiyao, 1a.

75. As Mårten Söderblom Saarela has usefully pointed out in comments, a parallel passage is found in another contemporary work: Sungyun, Emu tanggû orin sakda-i gisun sarkiyan: Erzählungen der 120 Alten: Beiträge zur mandschurischen Kulturgeschichte, ed. and trans. Giovanni Stary (Wiesbaden: Steiner, 1983), 267, 467. 
order to help students gain the minimal competence necessary to prevent humiliation, Fujun compiled "the sayings passed down by elders and [the phrases that I] remembered from studying ... and make the children of my clan study them. I called the book Essentials of the Manchu Language." (sakdasai ulandume gisurehe. mini tacifi ejehengge be . . . iktambufi. mini mukūn i deote juse be tacibuha. $)^{76}$ Manchu became a marker by which the bannermen, be they Mongol or Manchu or Han, asserted their position in banner society. Failure to speak the appropriate phrases entailed public humiliation. But even as Manchu became a marker of identity, the conversations in these textbooks tended to undermine the ideal frugal and martial "Manchu way" promoted by the court. This is further reflected in some of the materials produced by Manchu language students.

\section{Learners' Materials}

The previous two sections have detailed state-level concerns and some aspects of the new pedagogical genres. Whether inspired by loyalty to the dynasty or need of a regular stipend, bannermen learned Manchu, in many cases, as a second language. The popularity of Manchu study is evident in the large number of Manchu language pedagogical books engraved during the Qing. ${ }^{77}$ This section introduces three categories of unexplored informal materials used in Manchu language education. The similarity between each of these materials, and the abundance of such books in circulation, show that learning Manchu united students through shared pedagogical experiences. These genres, which are unique to Manchu language learners, illustrate the ways in which Manchu language pedagogy contributed to the development of a distinct identity among educated members of the Eight Banners. ${ }^{78}$

The first category of materials, which were produced during the early stages of Manchu language learning, were primarily conversation and exercise books, either original or copied manuscripts, and they reflect the muwa ("vulgar/simple") methodology of the conversations introduced by the textbooks of Sheng Qiliang and Wu-ge. Not all of these

76. Fujun, Qingwen zhiyao, 2b-3a.

77. Due to space constraints, I have not introduced many of these texts. For introductions to other pedagogical materials, see Tatiana Pang, "Mandschurische Sprachführer"; Zhao Lingzhi, "Qingdai Man-Han"; Elliott and Bosson, "Highlights," the list of references in Beijing shi minzu guji chubanshe, ed., Beijing diqu Manwen tushu zongmu 北京地区满文图书总 目 (Shenyang: Liaoning minzu chubanshe, 2008); and Giovanni Stary, “What's Where" in Manchu literature (Wiesbaden: Harrassowitz, 2005).

78. I am currently preparing an annotated bibliography of these works from across different collections. The present article draws mostly on materials held in the Harvard-Yenching Library. However, the Staatsbibliothek zu Berlin has an equally rich collection of these materials. Since these are being used by colleagues in Europe, I have decided to leave revelations about those materials to their studies. I look forward to work by Fresco Sam-Sin and his collaborators on the Manc.hu project. 


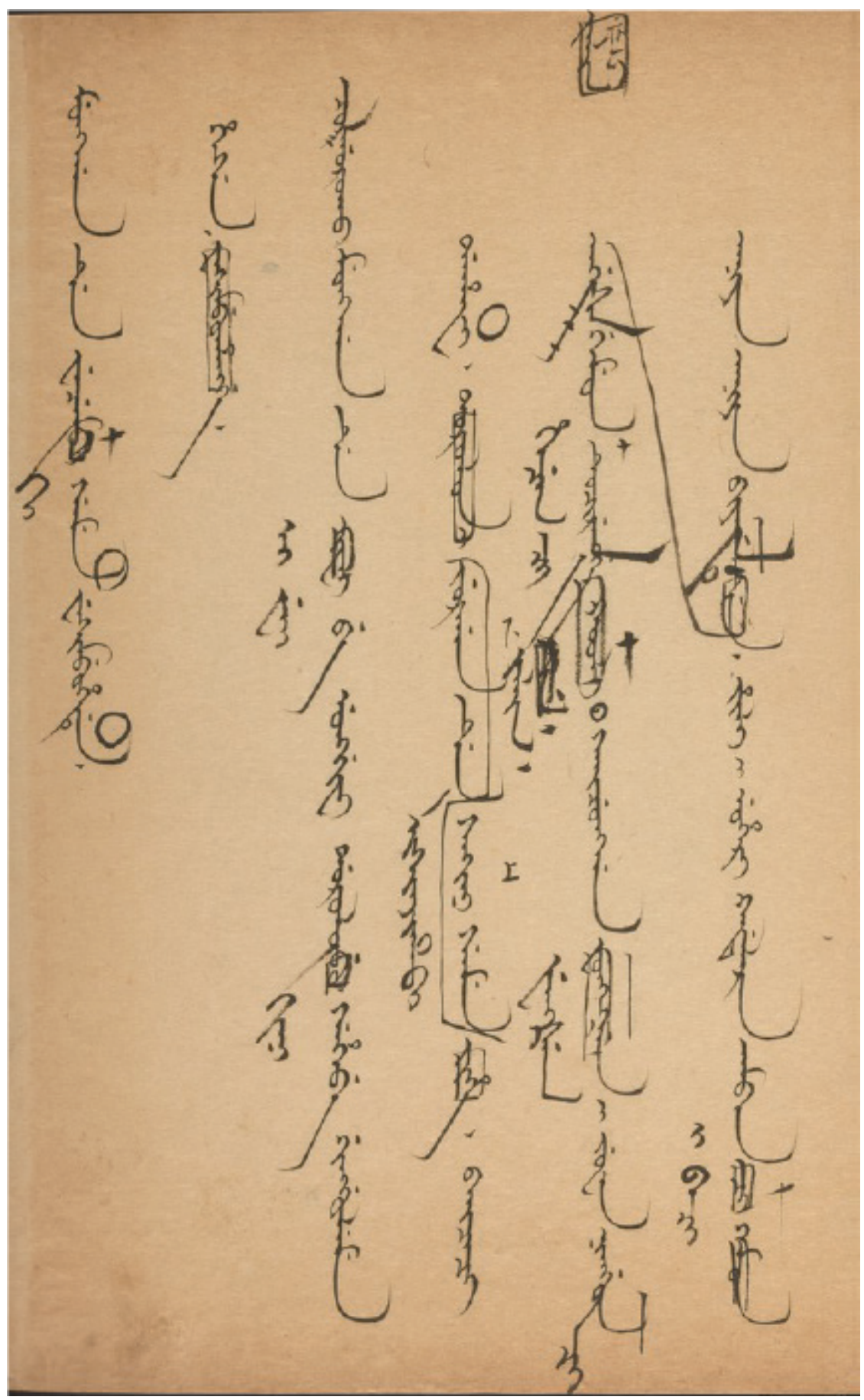

Examples of corrections in Daoguang Manyi Hanwen lianxi ce (道 光滿譯漢文練習冊), ca. 1820-50, ms., HarvardYenching Library, TMA 5806.05/3936. 
manuscripts are "original” compositions. Copying texts for study was a regular practice among Manchu language learners (something it shared with Chinese pedagogy). This practice seems to have been prominent before the engraving of The Manchu Preceptor. In one of Preceptor's model conversations, a soldier complains of his inadequate level of Manchu. After being criticized by his company captain for his bad Manchu, the soldier asks a friend, "Brother, if you have any Manchu books, would you lend me a few volumes? I would like to copy them." (age sinde aika manju bithe bici. emu udu debtelin juwen bureo. bi doolafi hūlambi. 阿哥你若有什麼滿州書, 想乞借與幾本。我抄了念.) His friend unfortunately had no books, but he praises the soldier's diligence and promises to ask among his acquaintances for volumes. ${ }^{79}$

In later periods, the widespread availability of conversation manuals should have theoretically made copying unnecessary. However, the presence of corrections (which may have been from a teacher) in many of these manuscript reproductions indicates that copying became an essential pedagogical practice. ${ }^{80}$ The aforementioned Dehi meyen, or Forty Exercises, which consists of forty separate dialogues on different topics, was a popular conversation manual. A manuscript of the text held by the Harvard-Yenching Library was laboriously copied by a student and shows corrections by the student's teacher. ${ }^{81}$ The same style of correction appears across all types of student produced materials, such as the many manuals purchased by Möllendorff that are now held at the Staatsbibliothek zu Berlin and in Krakow.

An example of original informal conversation materials is the manuscript produced by the secretary Na-ling 那齡 for his friend Qing-lin 慶麟. A draft of a request for sickleave inserted into the middle of the text tells us that Qing-lin was a Chinese-literate Mongol of the Plain Blue Banner. The conversations in the work are unique, and given their quotidian content, seem to have been derived from conversations between Na-ling and Qing-lin. It is possibly the only surviving example of Qing "water-cooler conversation." ${ }^{2}$ The text was composed with copying practices in mind. In a postscript to the work, Na-ling writes that he composed the text at Qing-lin's request so that he may have something to copy. ${ }^{83}$

These materials often describe the quotidian reality of life as a bannerman. Tenyear-old (11 sui) Leping was one of many students learning Manchu in late $18^{\text {th }}$-c. Beijing. ${ }^{84}$ His notebook, Muwa gisun, or Simple Talk, which was the product of his Manchu

79. Wylie, Translation, 93; Wu-ge, Cingwen, 36a-b.

80. For an example, see Ubaliyambuha dehi meyen-i bithe, n.d., ms., Harvard-Yenching Library, Ma5806.09/3206. This manuscript is unfoliated, so no page numbers are given. It should be noted that a high proportion of manuscript dictionaries, exercise manuals, and other Manchu texts has yet to be studied adequately. Manuscript production in both Chinese and Manchu for the late imperial period remains poorly understood.

81. Ubaliyambuha dehi meyen-i bithe.

82. Na-ling 那齡, Man-Han wen sanshi tiaozhi 滿漢文散事條治, n.d., ms., Harvard-Yenching Library, TMA 5161/3304.

83. Na-ling, Man-Han wen sanshi tiaozhi, page incipit minde ulabuha.

84. Leping's notebook is not structured in a narrative manner. This reconstruction of his daily life freely adapts different 
language class, illustrates both the Manchu pedagogical practices (correction) described above and the ways in which his identity as a bannerman was articulated through language pedagogy. ${ }^{85}$ Muwa gisun contains a hodge-podge of statements, many of which appear in other Manchu language textbooks, and presents a gateway into the world of Manchu pedagogy in the late Qing that allows for the reconstruction of a hypothetical student.

Because Leping's family was registered in the Bordered Red Banner, his small courtyard house was probably in the Manchu section of the city with the other families in the same banner, somewhere near the western gate (Fucheng men 阜成門). Leping was easily frustrated by many aspects of big city life. Whenever it rained, the streets were covered by mud too deep to bother leaving the house. He wrote,

Yesterday I had said I would go, but because it rained, I didn't go. Today I said I was going to go again, but with the streets turned to mud I didn't go. If it doesn't rain tomorrow, then I should be able to go.

bi sikse geneki sembihe. sikse agaha ofi tuttu genehekū. enenggi geli yabuki sere jakade. giyei de lifahan canggi. geli yabuhakū. cimari agarakū oci. uthai geneci ombi. ${ }^{86}$

He knew that this was not a very good excuse. Once, when trying to get out of another obligation, he complained that it was too slippery to go out. His unnamed conversation partner said, "It's not a problem. If you wear boots, why should you be afraid of mud? Tuck up your clothes like this and go." (hūwanggiyarakū. giyaban hülha etumbime geli lifahan de gelere aibi. tuttu sini etuku be fosomifi yabu. $)^{87}$ He took this advice, only to be splashed and soaked by a passing horse. ${ }^{88}$

Beijing was also too crowded. Once, he tried to sleep in the courtyard of his house. It was awkward to lie in the middle of the yard while his relatives passed in and out of the bathroom. Eventually, the stench of the outhouse forced him back indoors. ${ }^{89}$ Another time, his family's Pekinese dog bit the neighbor's cat. Leping's sage advice for resolving the row was to placate the neighbor's servant "with some nice words"

parts of his notebook in order to illustrate the ways in which a hypothetical Manchu finds his voice through materials produced while learning Manchu. I first learned of this notebook in seminar with Mark Elliott, He Bian, Hanung Kim, and others. Without Dr. Elliott's attention to this work, this paper would have never been conceived. The translations from the work were done together with this group, and so these following quotations are indebted to their collective work. Errors are my own, while any insightful observations are undoubtedly owed to this generous collective.

85. For more detail on this text, see: Jonathan Schlesinger, "Juicy Bits from the Archive: Toward an Environmental Microhistory: Lessons from the Muwa Gisun,” Late Imperial China 39, no. 2 (2018): 1-15.

86. Leping, Muwa gisun, discourse 4, 5b.

87. Leping, Muwa, discourse 30, 11b-12a.

88. Leping, Muwa, discourse 31, 12a.

89. Leping, Muwa, discourse 12, 7b. 
in order to "send him off and be done with it." 90 Muddy, rude, and smelly: This was Leping's city.

Life was not always frustrating for our young bannerman. He loved watching dashing banner soldiers assemble for inspection "At the place where weapons are inspected, it's so exciting! . . . You cannot hear anything but the sound of metal rattling. The brilliance of the weapons shining in the sunlight blinds you. It's truly magnificent."91 Unfortunately, Leping did not seem to have a future in soldiering. He was not very good at archery and lost interest after a few attempts to shoot from horseback. ${ }^{92}$ It may not have mattered very much anyway, for Leping, or the primer that he copied, said that he loved learning Manchu. ${ }^{93}$

This image of Leping would be lost to us if not for his notebook. Some of the content of Leping's notebook appears to be original, but some sections appear in other texts. For example, exercise eight, which reveals some of the social anxiety concerning learning Manchu, was copied from elsewhere:

Don't laugh. To laugh a lot is unlucky. [Besides,] we are all just students. When we get a single word wrong, why do you fall down laughing like that? How much could you know? How much are you able to understand? How dare you be so arrogant? ${ }^{94}$

ume injere. labdu injeci. urgun baita akū. muse gemu teni tacire niyalma. emu gisun tašaraha de uthai uttu fahame injembio. si giyanakū aibe sambi. aibe bahanambi. ai gelhūn akū uttu bardanggilambi.

Although the source of this passage has not been identified, this exact statement appears in another set of manuscript student notebooks, Manchu Language Exercises (Manzhou tiaohua 滿洲條話). ${ }^{95}$ Other sections of Leping's notebook are structurally similar to entries in popular conversation manuals, but the content is original to Leping. Often, it seems as though he was writing sentences to practice a certain grammar pattern, but at other times, it is clear that he was writing what he thought was humorous. Leping's context, like the context of all of the Manchu textbooks, was highly urban, filled with the excitement and sociability of Qing Beijing. ${ }^{96}$

90. Leping, Muwa, discourse 66, 20b.

91. Leping, Muwa, discourse 55, 18a-b

92. Leping, Muwa, discourse 34, 13a.

93. For an example of his enthusiasm for the language, see Leping, Muwa, discourse 16, 8b.

94. Leping, Muwa, discourse 8.

95. Manzhou huatiao 滿洲話條, n.d., ms., Harvard-Yenching Library, Ma5806.09/0621, vol. 6, page incipit ume injere.

96. For a detailed discussion of other extracts copied from primer, see: Author unknown, "Leping's Dog?," Tales of Manchu Life (blog), April 3, 2020, https://talesofmanchulife.wordpress.com/2020/04/03/lepings-dog/. 
Leping's notebook continues to show images of mischievous Manchu children depicted in textbooks such as Preceptor. The typical Manchu child was laughed at (hence the recurrence of the exclamation "Don't laugh at me!" in two separate manuscripts), frustrated by archery, and prone to other sorts of hijinks. In the case of Leping, his teacher corrected his grammar, but he never corrected the content of his notebooks. He did not seem to react to his bored Manchu student copying sentences such as:

Of the two of you, who is older? He is my elder. I am his junior. In terms of your knowledge, who is better? He is better than I. I do not measure up to him. Don't believe what he says. If you put the two of us in a pot and cooked us, we would taste the same. ${ }^{97}$

suweni juwe nofi we weci ahūn. ati i minci se ahūn. bi inci deo[.] suweni tacihangge. we weci fulu. $i$ minci fulu. bi inde isirakū. ini gisun be ume akdara. meni juwe niyalma be mucin de sindafi bujuci. amtan emu adali.

Occasional irreverence went hand in glove in Manchu copying exercises.

The second class of student's materials, probably the next materials produced by a student such as Leping, were written in preparation for the translation examinations. These texts range from parallel translations of colloquial Chinese and Manchu to more formal translations of edicts and philosophical essays. Two examples of this more advanced translation practice are Exercises in Manchu and Chinese (Qing-Han huatiao 清漢 話條) ${ }^{98}$ and A Notebook of Chinese-Manchu Translation (Man-Han fanyi biji ben 滿漢繙譯 筆記本). ${ }^{99}$

Exercises in Manchu and Chinese illustrates the movement from colloquial conversation to the production of expository prose. The notebook, written by an unnamed bannerman, consists of thirty-five dated Chinese entries, followed by their Manchu translation. The Manchu entries are all annotated, presumably by the translation instructor. This indicates that the Chinese entries were probably given as an assignment, which the student would then translate into Manchu. Although the entries are highly colloquial, they mostly abandon the dialogical format. The entries in Exercises, like those in earlier conversation books, cover a wide variety of topics, including family, friendship, morality, and ritual practices.

The most interesting sections discuss Mongol rituals in the wake of Mongol bannermen abandoning the steppes for life in Beijing. Entry seventeen begins by discussing

97. Leping, Muwa, discourse 11.

98. Qing-Han huatiao 清漢話條, n.d., ms., Harvard-Yenching Library, TMA 5806.09/0621.

99. Man-Han fanyi biji ben 滿漢繙譯筆記本, n.d., ms., Harvard-Yenching Library, TMA 5806.8/3326. 
the erection of wooden poles for prayer offerings to ancestors. It begins, "Brother, I'll tell you, the ancestors of us Mongol bannermen were originally nomadic. Early in the morning on the day of sacrifice [to the ancestors], we erect a prayer pole on a table in front of the house ..." The entry continues to detail the preparation of a sacrificial lamb, including the consumption of the meat. When the ritual was complete, the bones of the lamb were sent outside of the city, presumably in memory of their nomadic roots. ${ }^{100}$ These notebooks were often where students either articulated or were forced to articulate aspects of their banner identity.

A Notebook of Manchu and Chinese Translation reflects the highest level of preparation for the translation examinations. The notebook consists of parallel Manchu-Chinese translations of philosophical essays. Two other comparable examples of practice examination manuscripts are held by the Harvard-Yenching Library. Both A Practice Book for Translating Chinese into Manchu (Manyi Hanwen lianxi ce 滿譯漢文練習冊) and Daoguang Reign Practice Book for Translating Chinese into Manchu (Daoguang Manyi Hanwen lianxi $c e$ 道光滿譯漢文練習冊) contain examples of translated and corrected memorials and examination essays. ${ }^{101}$ The essays in these texts were clearly derived from the examination curriculum. They tend to discuss morality in the Four Books, government policies, and frontier affairs. These texts are usually heavily annotated and, given the importance of the translation examinations, would have been the most important part of a student's translation training.

The red annotations in the manuscript copy of Forty Exercises, Leping's notebooks, and more advanced translation materials are remarkably uniform. Without any official standardization, teachers seemingly taught and corrected in the same ways. By the early nineteenth century, a distinct pattern of Manchu language pedagogy had emerged. That pedagogy, in combination with the usage of similar learning materials, guaranteed that Manchu language students spread across the empire had similar educational experiences.

The uniformity of language pedagogy is further exemplified by the third and final category of materials: Language learning led students to produce and annotate a variety of mundane materials, including personal vocabulary lists, flash cards, songs, and heavily annotated dictionaries. These aids were produced and used by students at all levels.

Student lexicons came in a variety of formats. The notebook entitled Strings of Manchu (lian Qing yu 聯清語) is a collection of dated vocabulary entries, starting (as many do) with words relating to Heaven and other natural phenomena. Every four words in the notebook are dated, displaying the speed of vocabulary memorization and practice. ${ }^{102}$ Another lexicon written on a small format notebook was meant to be carried

100. Qing-Han huatiao 清漢話條, page incipit age si alame.

101. Daoguang Manyi Hanwen lianxi ce 道光滿譯漢文練習冊, ca. 1820-50, ms., Harvard-Yenching Library, TMA 5806.05/3936; Manyi Hanwen lianxi ce 滿譯漢文練習冊, 1806, ms., Harvard-Yenching Library, TMA 5806.8/3634. 102. Lian qingyu 聯清語 n.d., ms., Harvard-Yenching Library, TMA 5806.08/1300. 
with the student. ${ }^{103}$ However, lexicons were not always notebooks. Signs of student vocabulary practice appear on other Manchu texts. Readers of bilingual Chinese-Manchu novels were occasionally students. One owner of Jakdan's famous translation of Strange Tales from the Chatting Studio (Liaozhai zhiyi 聊齋誌異) used the top margins of his copy of the text to write a long Manchu vocabulary list. ${ }^{104}$ Another method of study involved the use of flash cards, of which a single example survives. ${ }^{105}$

Memorization of spelling and grammar was aided by songs or rhyming verses. Songbooks such as Songs for Early Guidance in Learning Manchu (Chuxue Manwen zhimeng ge 初學滿文指蒙歌) walked learners through the tricky aspects of the script with both images and songs. ${ }^{106}$ This text was probably written sometime in the last decades of the Qing, and it assumes a level of literacy in Chinese and Manchu from its audience. However, there were also both entirely Manchu and mixed language songs created for the sake of memorizing grammar. An early example of a mixed language Manchu-Chinese grammar ditty illustrates the importance of different tactics for memorizing in an environment where both languages were being used in conjunction:

$$
\begin{aligned}
& \text { esi 之下用 ci 托'ume 不可無 ra re ro (after an “esi” use a “ci," “ume” cannot lack } \\
& \text { “ra, re, ro") } \\
& \text { aika yala unenggi, 非 oc i即用 ohode... (If it is something true, then don't use } \\
& \text { “oci," use “ohode") }{ }^{107}
\end{aligned}
$$

All these materials together illustrate that students relied on a wide variety of informal texts and pedagogical practices throughout the course of their language studies. Primers were copied, songs were sung, dialogues were memorized, homework was corrected, and notes were taken on any available surface. The proliferation of these kinds of student materials resulted in surprisingly consistent institutional experiences and practices amongst Manchu language students and teachers. The redundancy of these works illustrates that the court's expectations for Manchu competency and the existence of well-defined pedagogical genres produced similar methods for Manchu language teaching, most of which are quite different from the more rote methodology usually seen in Chinese literacy training. Because of their Manchu language education, the bannermen were united by informal experiences in educational settings just as significantly as by the court's remonstrations

103. Xiuzhen biji 袖珍筆記, n.d., ms., Harvard-Yenching Library, TMA 5806.08/3180.

104. Pu Songling 蒲松齡, Jakdan trans., Ze fan “Liaozhai zhiyi” 擇繙聊齋志異 (1840), ms., Harvard-Yenching Library, TMA 5748/1046a. j. 32. Page incipit qing feng 青鳳.

105. The card in question fell out of the Harvard-Yenching copy of Qingwen huishu 清文彙書 | Manju gisun-i isabuha bithe (Beijing: Jingdu yinghua tang, 1750). Hopefully it is still there!

106. See Chaoben chuxue Manwen zhimeng ge 抄本初學滿文指蒙歌, n.d., ms., Minzu University Library, 552.1/6811.

107. Transcribed in Brian Tawney, "Reading Jakdan: An Exploration of Literary Manchu Phonology" (MA thesis, Harvard University, 2007), 163. The original poem is in Manzhou huatiao 滿洲話條. Tawney has also shared conversation and insight with me over several meetings. 
to follow the "Manchu way." The materials they used reflected their realities, providing a second ground for the development of an identity that set them apart from the majority of Han Chinese, and of the technical skills they needed to work as court translators.

\section{Conclusion}

In 1860, a Manchu noble wrote in his diary in Manchu, "From today on ... it is proper that I read good books and learn Manchu ... How dare I not earnestly study these fundamental matters?" (enenggi ci deribume. uthai saikan bithe hülame manjurara be tacici acambi. ai gelhun akū mujilen bantalame bengsen tacirakū ni.) After he finished this entry, he translated it into Chinese and put his book away. Despite his self-remonstration, he probably had more pressing matters than language practice. His grandfather's friends were making a social call tomorrow. Because they had been in mourning for the recently deceased Daoguang emperor, this would be the first visit of the New Year's season. Maybe they would be impressed by his newfound commitment to the dynastic language. It was more likely, however, that they would spend the day discussing new operas, perhaps occasionally asking him questions about his ambitions. ${ }^{108}$

During the Qing, the Manchu language was both symbolically and practically important. As the language of the ruling Manchu elites, it was proclaimed the "national language" (guoyu), and for the duration of the regime, the court emphasized the centrality of Manchu language to banner and state identity. The language was also essential to the regular operations of the Qing bureaucracy, which required armies of Manchu language competent translators and scribes. When Manchu language knowledge began to decline in the early Yongzheng period, the emperor vigorously responded by establishing schools and examinations to foster language competency among bannermen.

The bilingual nature of the Qing regime fostered major breakthroughs in the conceptualization of language acquisition. During the Kangxi reign, Shen Qiliang created a novel approach to the acquisition of foreign languages. In his textbook, he presented a comprehensive pedagogy for Manchu language acquisition that incorporated literacy, grammar, and conversation. Over the next century, more language aids were produced and circulated in response to court demands for Manchu competency among bannermen. These texts formed a unique corpus of pedagogical materials that enabled the continuation of Manchu language translation and communication.

Recently, scholars have begun to discuss what made the Qing an "empire." Like many other early modern empires, the Qing constituted its rule over large tracts of land through intentional policies of differentiation between subject groups, institutions

108. Riji Qing-Han tiaohua 日記清漢條話, 1861, ms., Peking University Library, 818.82/6033 1857, 9a. 
tailored to each group, and claims of cosmopolitan centrality on the part of the ruling elite. ${ }^{109}$ These arguments about empire neatly coincide with Charles Maier's definition of empire as "a form of political organization in which the social elements that rule in the dominant state-the 'mother country or metropole'-create a network of allied elites in regions abroad who accept subordination in international affairs in return for the security of their position in their own administrative unit." 110 Maintaining separation between subject groups relied on both coercion and subtle differentiation.

Language was an important part of Qing imperial ideology. As Patricia Berger has noted, Qing production and use of linguistic materials such as the famous pentaglot dictionary of Chinese, Manchu, Mongolian, Tibetan, and Chaghatay served, at least to the emperor himself, to ideologically construct Qing rulership over an empire of separate constituencies by defining meanings determined on the basis of empirical scholarship that was licensed by the authority of the state. ${ }^{111}$ During the Qianlong reign, the court's linguistic imperialism extended to include new and more "accurate" versions of dharani. ${ }^{112}$ Perhaps because the linguistic imperialism of high Qing officially sponsored scholarship presents some tempting expressions of language ideology, Manchu language learning materials have until recently been neglected in many modern accounts of Qing language politics.

However, if we view these pedagogical materials as a genre from a different perspective, they indicate not decline, but ingenuity. Manchu language textbooks with full curricula such as The Manchu Preceptor became a Qing "technology" for maintaining language competencies - that is, the textbooks were part of a complex of "linked sets of individuals, practices, and institutions"113 that helped maintain Qing official bilingualism. The technology of the language textbook-cum-curriculum-something that was unprecedented in China-developed together with Qing institutional expansion in the form of schools and the translation examinations. It contributed to the maintenance of empire by both ensuring the production of trained translators who enabled communication across the vast Inner Asian expanses of the Qing territories and regular translation

109. Work on the imperial nature of the Qing is quite voluminous. See: Crossley, Translucent Mirror; Peter C. Perdue, China Marches West: The Qing Conquest of Central Eurasia (Cambridge, Mass: Belknap Press of Harvard University, 2005); and Patricia Berger, Empire of Emptiness: Buddhist Art and Political Authority in Qing China (Honolulu: University of Hawaii Press, 2003). The legal segregation of separate parts of the empire is lucidly illustrated in David A. Bello, Opium and the Limits of Empire: Drug Prohibition in the Chinese Interior, 1729-1850 (Cambridge, Mass: Harvard University Asia Center, 2005).

110. Charles S. Maier, Among Empires: American Ascendancy and Its Predecessors (Cambridge, Mass: Harvard University Press, 2006), 7.

111. Berger, Empire of Emptiness, 37.

112. Zhang Hongwei 章宏偉, “Qingwen fanyi quanzang jing shuming, xiushu jigou, fanyi kanke shijian kao 《清文翻譯全藏 經》書名,修書機構,翻譯刊刻時間考, Fagu foxue xuebao 2 (2008): 321-22.

113. I am borrowing these words from Daqing Yang, Technology of Empire: Telecommunications and Japanese Expansion in Asia, 1883-1945 (Cambridge, Mass: Harvard University Asia Center, 2010), 9, where they are used in a different context. 
activities in Beijing, and by contributing to the maintenance of a unique identity among member of the Eight Banners.

\section{Bibliography}

Bai, Limin. Shaping the Ideal Child: Children and Their Primers in Late Imperial China. Hong Kong: The Chinese University Press, 2005.

Bartlett, Beatrice S. Monarchs and Ministers: The Grand Council in Mid-Ching China, 1723-1820. Berkeley: University of California Press, 1991.

Beijing shi minzu guji chubanshe 北京市民族古籍出版社, ed. Beijing diqu Manwen tushu zongmu 北 京地区满文图书总目. Shenyang: Liaoning minzu chuban she, 2008.

Bello, David A. Opium and the Limits of Empire: Drug Prohibition in the Chinese Interior, 1729-1850. Cambridge, Mass: Harvard University Asia Center, 2005.

Bolton, Kingsley. Chinese Englishes: A Sociolinguistic History. Cambridge, UK: Cambridge University Press, 2003.

Berger, Patricia. Empire of Emptiness: Buddhist Art and Political Authority in Qing China. Honolulu: University of Hawai'i Press, 2003.

Brokaw, Cynthia Joanne. Commerce in Culture: The Sibao Book Trade in the Qing and Republican Periods. Cambridge, Mass.: Harvard University Asia Center, 2007.

Brophy, David. "The Junghar Mongol Legacy and the Language of Loyalty in Qing Xinjiang." Harvard Journal of Asiatic Studies 73, no. 2 (2013): 231-58.

Changshan 長善, ed. Zhu Yue baqi zh 讷粤八旗志. Shenyang: Liaoning daxue chubanshe, (1879) 1990.

Chaoben chu xue Manwen zhimeng ge 抄本初學滿文指蒙歌, n.d. Manuscript, 552.1/6811. Minzu daxue tushuguan.

Chen Zhiming 陳志明. “Gu hanyu xuci yanjiu shi shulue” 古汉语虚词研究史述略. Shanxi daxue xuebao 2 (1994): 86-88.

Chunhua 春花. Qingdai Man Meng wen cidian yanjiu 清代满蒙文词典研究. Shenyang: Liaoning minzu chubanshe, 2008.

Crossley, Pamela Kyle. A Translucent Mirror: History and Identity in Qing Imperial Ideology. Berkeley: University of California Press, 1999.

- . "Manchu Education." In Education and Society in Late Imperial China, 1600-1900, edited by Benjamin A. Elman and Alexander Woodside, 340-78. University of California Press, 1994.

Crossley, Pamela Kyle, and Evelyn S. Rawski. "A Profile of The Manchu Language in Ch'ing History." Harvard Journal of Asiatic Studies 53, no. 1 (1993): 63-102.

Daoguang Manyi Hanwen lianxi ce 道光滿譯漢文練習冊. ca. 1820-50. Harvard-Yenching Rare Books Collection. Manuscript, TMA 5806.05/3936. Harvard-Yenching Library.

Dyer, Svetlana R. K. Grammatical Analysis of the Lao Ch'i-Ta: With an English Translation of the Chinese Text. Canberra: Faculty of Asian Studies, Australian National University, 1983.

De Groot, Henk. "The Study of the Dutch Language in Japan During Its Period of National Isolation (ca. 1641-1868)." PhD diss., University of Canterbury, 2005.

Elliott, Mark C. The Manchu Way: The Eight Banners and Ethnic Identity in Late Imperial China. Stanford, Calif.: Stanford University Press, 2001.

— . "The Manchu-Language Archives of the Qing Dynasty and the Origins of the Palace Memorial System." Late Imperial China 22, no. 1 (2001): 1-70. 
Elliott, Mark C., and James E. Bosson. "Highlights of the Manchu-Mongol Collection in the Harvard-Yenching Library," in Treasures of the Yenching: Seventy-Fifth Anniversary of the Harvard-Yenching Library Exhibition Catalogue, edited by Patrick Hanan, 79-121. Cambridge, Mass.: Harvard-Yenching Library, 2003.

Elman, Benjamin A. Civil Examinations and Meritocracy in Late Imperial China. Cambridge, Mass.: Harvard University Press, 2013.

Fujun 富俊. Xinkan Qingwen zhiyao 新刊清文指要. Xi'an: Xi'an jiangjun shunei, 1818.

Gorelova, Liliya M. Manchu Grammar. Leiden: Brill, 2002.

Hsiung, Hansun. "Book-keeping Moderniz'd: The Textbook from Mimesis to Method." Unpublished seminar paper. Harvard University, 2011.

Numata, Jiro, "The Introduction of Dutch Language." Monumenta Nipponica 19, no. 3/4 (1964) 243-53.

Kim Ch’ang-ŏp 金昌業. Yŏnhaeng ilgi 燕行日記. Vol. 31. Yŏnhaengnok chŏnjip. Seoul: Tongguk taehakkyo ch'ulp'anbu, 2001.

Lian qingyu 聯清語. n.d. Harvard-Yenching Rare Books Collection. Manuscript, TMA 5806.08/1300. Harvard-Yenching Library.

Lin Dongxi 林東錫. “Chaoxian yixue kao” 朝鮮譯學考. PhD. diss, Taiwan shifan daxue, 1982.

Liu Xiaomeng 刘小萌. Qing dai Beijing qiren shehui清代北京旗人社会. Beijing: Zhongguo shehui kexue chuban she, 2008.

Leping. Muwa gisun. n.d. Harvard-Yenching Rare Books Collection. Manuscript, Ma5806.09/0622. Harvard-Yenching Library.

Leung, Angela Ki Che. "Medical Instruction and Popularization in Ming-Qing China." Late Imperial China 24, no. 1 (2003): 130-52.

Liu Man 劉曼 and Zhang Meilan 張美蘭. “Qingdai zhuming de Man-Han shuangyu jiaocai 'Qingwen zhiyao’ (bai zhang) ji qi jiazhi” 清代著名的滿漢雙語教材《清文指要》(百章)及其價值. Haiwai huawen jiaoyu 海外華文教育, 62, no. 1 (2012), 89-94.

Lufrano, Richard John. Honorable Merchants: Commerce and Self-Cultivation in Late Imperial China. Studies of the East Asian Institute. Honolulu: University of Hawai'i Press, 1997.

Maier, Charles. Among Empires: American Ascendancy and Its Predecessors. Cambridge, Mass: Harvard University Press, 2006.

Man-Han fanyi biji ben 滿漢繙譯筆記本. n.d. Harvard-Yenching Rare Books Collection. Manuscript, TMA 5806.8/3326. Harvard-Yenching Library.

Manyi Hanwen lianxi ce 滿譯漢文練習冊. 1806. Harvard-Yenching Rare Books Collection. Manuscript, TMA 5806.8/3634. Harvard-Yenching Library.

Manzhou huatiao 滿洲話條. n.d. Harvard-Yenching Rare Books Collection. Manuscript, Ma5806.09/062. Harvard-Yenching Library.

“Ming Qing shilu” 明清實錄. Accessed August 21, 2016. http://sillok.history.go.kr/mc/searchResultList.do.

Na-ling 那齡. Man-Han wen sanshi tiaozhi 滿漢文散事條治. n.d. Harvard-Yenching Rare Books Collection. Manuscript, TMA 5161/3304. Harvard-Yenching Library.

Kanda Nobuo. "Shen Ch'i-liang and His Works on the Manchu Language" in Proceedings of the Third East Asian Altaistic Conference, eds. Ch'en Chieh-hsien and Sechin Jagchid, 129-43. Taipei: Taiwan University, 1969.

Oidtmann, Max. Forging the Golden Urn: The Qing Empire and the Politics of Reincarnation in Tibet. New York: Columbia University Press, 2018. 
Ogura Shinpei 小倉進平. Chōsengogaku shi 朝鮮語学史. Tōkyō: Tōkō Shoin, 1964.

Pang, Tatjana A. "Mandschurische Sprachführer aus der Sammlung der Leningrader Abteilung des Orientalischen Instituts der Akademie der Wissenschaften." Central Asiatic Journal 32, no. 1/2 (1988): 91-97.

Perdue, Peter. China Marches West: The Qing Conquest of Central Eurasia. Cambridge, Mass.: Belknap Press of Harvard University, 2005.

Porter, David. "Bannermen as Translators: Manchu Language Education in the Hanjun Banners." Late Imperial China 40, no. 2 (2019): 1-43.

Pu Songling 蒲松齡, Jakdan trans. Ze fan liao zhai zhi yi 擇繙聊齊志異. Beijing: NP, 1840?. HarvardYenching Rare Books Collection. TMA 5748/1046a. Harvard-Yenching Library.

Qing-Han huatiao 清漢話條. n.d. Harvard-Yenching Rare Books Collection. Manuscript, TMA 5806.09/0621. Harvard-Yenching Library.

Riji Qing Han tiaohua 日記清漢條話. 1861. Manuscript, 818.82/6033 1857. Beijing University Library.

Qingwen huishu 清文彙書 | Manju gisun- $i$ isabuha bithe. Beijing: Jingdu yinghua tang, 1750.

Rawski, Evelyn S. "Qing Publishing in Non-Han Languages." In Printing and Book Culture in Late Imperial China, edited by Cynthia Brokaw, 304-25. University of California Press, 2005.

Rhoads, Edward J. M. Manchus \& Han: Ethnic Relations and Political Power in Late Qing and Early Republican China, 1861-1928. Studies on Ethnic Groups in China. Seattle: University of Washington Press, 2000.

Ruys, Juanita Feros. "Introduction: Approaches to Didactic Literature-Meaning, Intent, Audience, Social Effect." In What Nature Does Not Teach: Didactic Literature in the Medieval and EarlyModern Periods. Turnhout: Brepols Publishers, 2008.

Schlesinger, Jonathan. "Juicy Bits from the Archive: Toward an Environmental Microhistory: Lessons from the Muwa Gisun." Late Imperial China 39, no. 2 (2018): 1-15.

Shen Qiliang 沈啓亮. Qingshu zhinan 清書指南. Blockprint. NP: 1682.

Söderblom Saarela, Mårten. "Linguistic Compartmentalization and the Palace Memorial System in the Eighteenth Century." Late Imperial China 41, no. 2 (2020): 131-79.

- The Early Modern Travels of Manchu: A Script and Its Study in East Asia and Europe. Philadelphia: University of Pennsylvania Press, 2020.

—. "Shier Zitou Jizhu (Collected Notes on the Twelve Heads): A Recently Discovered Work by Shen Qiliang." Saksaha: A Journal of Manchu Studies 12 (2014): 9-31.

_. "Manchu and the Study of Language in China (1607-1911)." PhD diss., Princeton University, 2015.

Song Luofen 嵩洛峰. Xinyu Qingwen jiezi 新語清文接字. Beijing: Fanyi shufang, 1898.

Stary, Giovanni. "What's Where" in Manchu Literature. Wiesbaden: Harrassowitz in Kommission, 2005.

Sungyun. Emu tanggû orin sakda-i gisun sarkiyan: Erzählungen der 120 Alten: Beiträge zur mandschurischen Kulturgeschichte. Edited and translated by Giovanni Stary. Wiesbaden: Steiner, 1983.

Takekoshi, Takashi. "Grammatical Descriptions in Manchu Grammar Books from the Qing Dynasty." Histoire Epistémologie Langage 41, no. 1 (2019): 39-55.

Talesofmanchulife. "Leping's Dog?" Tales of Manchu Life (blog), April 3, 2020. https://talesofmanchulife.wordpress.com/2020/04/03/lepings-dog/.

Tawney, Brian. "Reading Jakdan: An Exploration of Literary Manchu Phonology." MA thesis, Harvard University, 2007. 
Trachsel, Yves. "Substance Abuse Among Bannermen and Banner Self-Perception: An Analysis of Qing Language Primers." Saksaha: A Journal of Manchu Studies 15 (2018).

Ubaliyambuha dehi meyen-i bithe. n.d. Harvard-Yenching Rare Books Collection. Manuscript, Ma5806.09/3206. Harvard-Yenching Library.

Wang Li 王麗. “Qingdai fanyi ke shulun 清代翻譯科述論.” Liaoning daxue xuebao 29, no. 4 (2012): 40-43.

Wang, Sixiang. "Chosŏn's Office of Interpreters: The Apt Response and the Knowledge Culture of Diplomacy." Journal for the History of Knowledge 1, no. 1 (2020): 1-15.

Wild, Norman. "Materials for the Study of the Ssǔ I Kuan 四夷 (譯) 管 (Bureau of Translators)." Bulletin of the School of Oriental and African Studies 11, no. 3 (1945): 617-40.

Wu, Silas H. L. Communication and Imperial Control in China Evolution of the Palace Memorial System, 1693-1735. Cambridge, Mass.: Harvard University Press, 1970.

Wu-ge 舞格. Cingwen kimeng bithe | Qingwen qimeng 清文啟蒙. Beijing: Jingdu yinghua tan, 1730.

Wylie, Alexander. Translation of the Ts'ing Wan K'e Mung, a Chinese Grammar of the Manchu Tartar Language: With Introductory Notes on Manchu Literature. Shanghai: London Mission Press, 1855.

Xiyuan 希元, ed. Jingzhou zhufang baqi zhi 荆州驻防八旗志. Shenyang: Liaoning daxue chubanshe, (1879) 1990.

Xiuzhen biji 袖珍筆記. n.d. Harvard-Yenching Rare Books Collection. Manuscripts, TMA 5806.08/3180. Harvard-Yenching Library.

Yang, Daqing. Technology of Empire: Telecommunications and Japanese Expansion in Asia, 18831945. Cambridge, Mass: Harvard University Asia Center, 2010.

Yeh Kao-shu 葉高樹. “Qingchao de fanyi kekao zhidu 清朝的繙譯科考制度.” Taiwan shida lishi xuebao, no. 49 (2013): 47-136.

—. "Qingchao de qixue yu qiren de fanyi jiaoyu 清朝的旗學與旗人的繙譯教育." Taiwan shida lishi xuebao, no. 48 (2012): 71-154.

- Qingchao qianqi de wenhua zhengce 清朝前期的文化政策. Banqiao: Daoxiang chuban she, 2002.

Yongzheng Emperor. Shangyu baqi 上諭八旗. Beijing: Wuying dian, 1741.

Yu, Li. "Character Recognition: A New Method of Learning to Read in Late Imperial China." Late Imperial China 33, no. 2 (2012): 1-39.

Zhan Hongmou 詹鴻謨, ed. Qinding kechang tiaoli 欽定科場條例. Beijing: Neiwufu, 1887.

Zhang Hongwei 章宏偉, “'Qingwen fanyi quanzang jing' shuming, xiushu jigou, fanyi kanke shijian kao”《清文翻譯全藏經》書名, 修書機構, 翻譯刊刻時間考. Fagu foxue xuebao, no. 2 (2008): 321-22.

Zhao Lingzhi 赵令志. “Qingdai Man-Han Hebi he bi zicishu jiqi zuoyong tanxi 清代满汉合璧字辞 书及其作用探析.” Manyu Yanjiu 滿語研究, no. 2 (2009): 65-70.

Zou Changqing 㚿長清. “Qingdai fanyi ke kaolun 清代翻譯科考論.” Shijiazhuang xueyuan xuebao 14, no. 5 (2012): 23-33. 